Biol. Neonate 1975;26:I-V

\title{
Contents, Vol. 26, 1975
}

\section{Contents}

Luit, H.; Berger, R., and Hommes, F.A.: Fatty Acid Composition of some Cellular Membranes of Fetal Rat Liver 1

Kraan, G.P.B. and Dias, T.: Size of L-Lactate Transport from the Fetal Rat to the Mother Animal 9

Myers, R.E.: Fetal Asphyxia due to Umbilical Cord Compression. Metabolic and Brain Pathologic Consequences 21

Emery, J.L. and Dinsdale, F.: Lymphoreticular Aggregates in the Newborn Lung and Their Relation to Intrauterine Infection and Neurospinal Dysraphism 44

Blum, D. and Brauman, J.: Serum Enzymes in the Neonatal Period. Diagnostic Aid in Muscle Pathology 53

Short, C.R.; Sexton, R.L., and McFarland, K.: Binding of 14C-Salicylic Acid and 14C-Pentobarbital to Plasma Proteins of Several Species During the Perinatal Period 58

Seem, E. and Wille, L.: Salicylate Saturation Index in Neonatal Jaundice 67 Vernier, M.C.: Sex-Differential Placentation Immunological Interactions between Male Conceptus and Gravida during Normal Pregnancy 76

Berry, H.K.; Butcher, R.E.; Kazmaier, K.J., and Poncet, LB.: Biochemical Effects of Induced Phenylketonuria in Rats 88

Berry, H.K.; Poncet, LB.; Sutherland, B.S., and Burkett, R.: Serum Amino Acid Concentrations during Pregnancy of Women Heterozygous for Phenylketonuria . 102 Thomas, A.L.; Jack, P.M.B.; Manns, J.G., and Nathanielsz, P.W.: Effect of Synthetic Thyrotrophin Releasing Hormone on Thyrotrophin and Prolactin Concentra tions in the Peripheral Plasma of the Pregnant Ewe, Lamb Fetus and Neonatal Lamb 109

Noble, R.C.; Crouchman, M.L., and Moore, J.H.: Plasma Cholesterol Ester Formation in the Neonatal Lamb 117

Burchell, B. and Dutton, G.J.: Delayed Induction by Phenobarbital of UDP-Glucuronyltransferase Activity towards Bilirubin in Fetal Liver 122

\section{Contents}

IV

Gårdmark, S.; Gennser, G,; Jacobson, L.; Rooth, G., and Thorell, /.: Influence on Fetal Carbohydrate and Fat Metabolism and on Acid-Base Balance of Glucose Administration to the Mother during Labour 129

Wu, P.Y.K. and Yoshida, T.: Changes in Cellular Growth in Newborn Rats and Rabbits Exposed to Photoirradiation 146

Pontonnier, G.; Puech, F.; Grandjean, H., and Rolland, M.: Some Physical and Bio chemical Parameters during Normal Labour. Fetal and Maternal Study 159 Le Gal, Y.M.: Characterization and Quantitation of the Five Major Plasma Protein 
Fractions in Seven-Day-Old Piglets 174

Alexander, G. and Bell, A.W.: Maximum Thermogenic Response to Cold in Relation to the Proportion of Brown Adipose Tissue and Skeletal Muscle in the Body and to other Parameters in Young Lambs 182

Jack, P.M.B. and Milner, R.D.G.: Effect of Decapitation and ACTH on Somatic Development of the Rabbit Fetus 195

Girard, J.R. and Zeghal, N.: Adrenal Catecholamines Content in Fetal and Newborn

Rats. Effects of Birth by Caesarian Section, Cold Exposure, Hypoxia, Hypo-

glycemia and 2-Deoxyglucose 205

Alexander, G. and Bell, A.W.: Quantity and Calculated Oxygen Consumption during

Summit Metabolism of Brown Adipose Tissue in New-Born Lambs 214

Marthens, E., van; Harel, S., and Zamenhof, S.: Experimental Intrauterine Growth

Retardation. A New Animal Model for the Study of Altered Brain Development 221

Baetz, A.L.; Hubbert, W.T., and Graham, C.K.: Developmental Changes of Tissue

Enzyme Patterns in the Bovine Fetus with Gestational Age 232

Usher, R.H.; Saigal, S.; O’Neill, A.; Surainder, Y., and Chua, L.-B.: Estimation of Red

Blood Cell Volume in Premature Infants With and Without Respiratory Distress

Syndrome 241

Henning, S.J.; Helman, T.A., and Kretchmer, N.: Studies on Normal and Precocious

Appearance of Jejunal Sucrase in Suckling Rats 249

Hummel, L.; Schirrmeister, W., and Wagner, H.: Quantitative Evaluation of the

Maternal-Fetal Transfer of Free Fatty Acids in the Rat 263

Moskalewski, S.; Ptak, W., and Czarnik, Z.: Demonstration of Cells with IgG Recep

tor in Human Placenta 268

Zamet, P.; Nakamura, H.; Perez-Robles, S.; L·arroche, J.C., and Minkowski, A.: The

Use of Critical Levels of Birth Weight and Tree Bilirubin' as an Approach for

Prevention of Kernicterus 274

Gellert, R.J. and Heinrichs, W. L·eRoy: Effects of DDT Homologs Administered to

Female Rats during the Perinatal Period 283

Oh, W.; Omori, K.; Hobel, C.J.; Erenberg, A., and Emmanouilides, G.C.: Umbilical

Blood Flow and Glucose Uptake in Lamb Fetus Following Single Umbilical

Artery Ligation 291

Nuwayhid, B.; Brinkman, C.R., III; Su, C; Bevan, J.A., and Assali, N.S.: Systemic

and Pulmonary Hemodynamic Responses to Adrenergic and Cholinergic Ago

nists during Fetal Development 301

Stave, U.: Perinatal Changes of Interorgan Differences in Cell Metabolism

Rubaltelli, F.F.; Donzelli, F., and Largajolli, G.: Effect of Phototherapy on Hepatic-Excretory

Function in Newborns as Measured by Bromsulphalein Clearance . . 333

Belgaumkar, T.K. and Scott, K.E.: Effects of Low Humidity on Small Premature

Infants in Servocontrol Incubators. I. Decrease in Rectal Temperature 337

Belgaumkar, T.K. and Scott, K.E.: Effects of Low Humidity on Small Premature

Infants in Servocontrol Incubators. II. Increased Severity of Apnea 348

Contents

$\mathrm{V}$

Michelsson, K.; Sirviö, P.; Koivisto, M.; Sovijärvi, A., and Wasz-Höckert, O.: Spectrographic Analysis of Pain Cry in Neonates with Cleft Palate 
Shimada, M.; Wakaizumi, S., and Kusunoki, T.: Developmental Abnormality of the Retina Caused by Postnatal Administration of Cytosine Arabinoside 359

Djaldetti, M.; Ovadia, J.; Bessler, H.; Fishman, P., and Halbrecht, I.: Ultrastructural Study of the Erythropoietic Events in Human Embryonic Livers

Varia 300

Author Index 375

Subject Index 376 